\title{
Dançando estruturas: Lévi-Strauss, Alfred Gell e a dança contemporânea
}

\author{
L Renato JacQues de Brito Veiga \\ Universidade de Sáo Paulo, Sáo Paulo, Sáo Paulo, Brasil
}

DOI 10.11606/issn.2316-9133.v24i24p18-42

\begin{abstract}
resumo $\mathrm{O}$ que a dança faz? $\mathrm{O}$ dançarino é quem pensa seu corpo ou é seu corpo que o pensa? Quantos corpos cabem num corpo, quantas pessoas podem ser um corpo? Qual corpo? Pode a dança ser considerada análoga à poesia, por transformar no corpo o que a poesia transforma na língua? Este ensaio é fruto da imersão etnográfica no universo dos ensaios do Núcleo Artérias, grupo de dança contemporânea da cidade de São Paulo dirigido pela coreógrafa Adriana Grechi. Meus interlocutores aqui, além de Adriana, são cinco dançarinas e duas obras de dança contemporânea, Fleshdance (2012) e Bananas (2013), cujos processos de criação acompanhei de cabo a rabo. A proporção teórica deste ensaio é fruto da leitura de dois autores em especial, Claude Lévi-Strauss e Alfred Gell, que me levam a pensar/propor uma abordagem estrutural como ponto de partida para se pensar a dança contemporânea.
\end{abstract}

palavras-chave Dança contemporânea; Processos criativos; Estruturalismo; Alfred Gell; Lévi-Strauss.

\section{Dancing Structures: Lévi-Strauss, Alfred Gell and contemporary dance}

abstract What is dance? Is the dancer who thinks their body or their body who thinks the dancer? How many bodies fit a body, how many people can be a body? Which body? Can we consider dance analogous to poetry, for transforming in the body what poetry does in verbal language? This essay is the result of an ethnographic immersion in the world of the rehearsals of Núcleo Artérias, contemporary dance group from São Paulo, directed by choreographer Adriana Grechi. My interlocutors here, besides Adriana, are five dancers and two works of contemporary dance, Fleshdance (2012) and Bananas (2013), which creation processes I accompanied entirely. The theoretical portion of this essay is the result of two readings in particular, Claude Lévi-Straus and Alfred Gell, which lead me to thinking/proposing a structural approach as a starting point to think contemporary dance.

keywords Contemporary dance; Creative processes; Structuralism; Alfred Gell; Lévi-Strauss. 
But what about the dancer? Is she human? Of course she really is, but, on the stage, she seems inhuman or impersonal - perhaps superhuman. I don't know.

Gregory Bateson, 1972

\section{Dançando estruturas, um prólogo}

No "Finale" de $O$ homem nu, Lévi-Strauss (2011) afirma que o campo dos estudos estruturais inclui quatro famílias de ocupantes principais: os seres matemáticos, as línguas naturais, as obras musicais e os mitos. Algumas dissimetrias quanto à relação entre som e sentido se instalam entre essas quatro famílias, fazendo com que cada uma delas gire e pendule ora se aproximando, ora se afastando uma da outra. E o que aconteceria se nos propuséssemos a interpelar o campo dos estudos estruturais acrescentando a esse quarteto um quinto elemento: a dança?

Como escreve Lévi-Strauss, as entidades matemáticas são estruturas em estado puro, livres de qualquer encarnação, são opostas aos fatos linguísticos que só existem na interseção entre som e sentido. A matemática é ausência de som e sentido. Já a música e o mito, cada um, são uma linguagem de que algo, ou o sentido ou o som, teria sido omitido. As estruturas musicais estáo mais para o lado do som, e as estruturas míticas, mais para o lado do sentido. A música é linguagem menos sentido. $\mathrm{O}$ mito é linguagem menos som.

Desse ponto de vista, a dança seria uma espécie de matemática encarna$d a$, na qual a estrutura encontra-se descolada do som e do sentido, porém inscrita direta e profundamente no corpo. A dança prescinde do som, a dança se exime do sentido. Mas opostamente à matemática, nesse aspecto, a dança é pura encarnação, ela existe na interseção encarnada dessa dupla ausência de som e de sentido. A dança seria uma linguagem à qual tanto som quanto sentido teriam sido retirados, mas é estrutura em estado corpóreo, uma espécie de duplo encarnado da matemática. É por isso que a dança é naturalmente acompanhada de música, e é por isso que somos irremediavelmente levados a suprir o seu sentido ausente. A dança carece de sentido, pois foi desvinculada deste. A dança prescinde do som, pois é sua perfeita imagem em negativo, no corpo. A dança se aproxima da matemática, mas diferentemente desta, possui uma carência intrínseca de sentido e uma relação metonímica com o som.

O mito, ao ser narrado, incorre em tentativas de recuperação do som que lhe falta, diz Lévi-Strauss. E ao que tudo indica, o mito, ao ser narrado, deve ser também dançado. 
O mito é atraído pelo sentido como por um ímã; e essa aderência parcial cria, do lado do som, um vazio virtual que o narrador se sente compelido a suprir com diversos procedimentos - efeitos vocais ou gestuais que nuançam, modulam e reforçam o discurso [...] e a recitação é quase sempre acompanhada de gestos e fórmulas convencionais. Além disso, as cenas estão presentes para o narrador, que sabe torná-las presentes também para quem o escuta; ele as vê acontecendo diante de si, vive-as, e comunica essa experiência com a mímica e a gesticulação apropriadas. Acontece inclusive de o mito ser executado várias vozes e tornar-se representação teatral. (LÉVI-STRAUSS, 2011, p. 625)

A dança é o movimento que outrora acompanhava a narrativa do mito numa tentativa de recuperaçáo do som. A dança é o procedimento que vem suprir esse vazio virtual, produzindo no corpo, em negativo, uma imagem e semelhança do som ausente. A dança, matemática encarnada, é também música silenciosa. Como na música, sua função significante se mostra irredutível a tudo o que seria possível para ela expressar ou traduzir em forma verbal. "Ela [a música] se exerce abaixo da língua" (LÉVI-STRAUSS, 2011, p. 626). No caso da dança, da língua para dentro.

Segundo Lévi-Strauss, a música e a literatura, ao se tornarem modernas, repartem entre si as heranças do mito, restando a música com sua forma e a literatura com seus resíduos desformalizados. Sugiro que a dança seja o negativo, no corpo, da música, sendo-lhe simétrica frente à herança do mito, restando também ela com sua forma menos seu sentido, o que explica por que estamos sempre em busca de um sentido para a sua forma. A dança, como a música, pertenceu um dia ao mito, e ao que tudo indica, a lógica do pensamento mítico segue exercendo nela sua força quase invisível. Abre-se aqui a perspectiva de corpos que se pensam entre si, além de corpos que se pensam naqueles que dançam. O corpo se pensa no dançarino, o corpo se restaura através do dançarino, por meio de lógicas em grande medida inconscientes.

A significação da dança, assim como da música, escapa ao entendimento intelectual, visto que se prende diretamente na sensibilidade. Assim como a música, a dança nos transforma em seres de qualidade diferente, nos quais "princípios normalmente incompatíveis [...] se apaziguam e atingem, ao se reconciliarem, uma espécie de unanimidade orgânica" (LÉVI-STRAUSS, 2011, p. 663). "Unanimidade orgânica”, expressão que chega mesmo a sintetizar o leitmotiv da dança, o engajamento pleno entre o sensível e o inteligível, através do qual a alma é "convidada excepcionalmente a se reconhecer no corpo” (LÉVI-STRAUSS, 2011, p. 633). 
A análise estrutural, como afirma Lévi-Strauss, só pode surgir no espírito, trazendo verdades profundas e orgânicas, porque seu modelo já está no corpo. $\mathrm{O}$ exercício do pensamento estrutural permite validar as intuiçóes do pensamento selvagem, operando comunicaçóes entre o espírito e o corpo, abrindo passagens reconciliatórias entre o sensível e o inteligível, entre o qualitativo e o geométrico (LÉVI-STRAUSS, 2011, p. 668). A dança é o lugar em que a alma é mais que nunca convidada a se reconhecer no corpo, exigindo uma convocaçáo total do ser. A dança, portanto, acrescenta o corpo à estrutura lévi-straussinana, que então se encarna.

\section{Fleshdance, excertos etnográficos de uma dança respiratória}

Em princípios de 2012, o Núcleo Artérias dá início à criação de sua nova obra, Fleshdance. A obra é dirigida por Adriana Grechi, dançada por Nina Giovelli, Larissa Ballarotti e Juliana Ferreira, com vídeos de André Menezes, trilha de Dudu Tsuda e iluminação de André Boll.

Estúdio Nave, Vila Madalena, São Paulo. Ensaio do novo trabalho de dança contemporânea do Núcleo Artérias, Fleshdance. Tem início o aquecimento, a preparação dos corpos. A música é calma, o ambiente é de sossego, há um aconchego no lugar onde se ensaia. Não se ensaia em qualquer lugar. Afinal, é preciso resguardo, é preciso alguma segurança para estender o corpo. Os corpos se prolongam numa sala de aproximadamente oitenta metros quadrados em sessóes de alongamento que podem durar uma hora. Silêncio, concentração.

O início dos ensaios do Artérias consiste sempre nessa preparaçáo minuciosa do corpo, que o predispóe a sua própria experimentação, que o libera para adentrar da forma mais receptiva possível os "estados alterados" que irá atingir ao longo do ensaio. Esse primeiro momento é um estado de passagem, algo que marca uma transição. Trata-se de um uso cuja função é ativar a corporeidade. $\mathrm{O}$ corpo, durante a sua preparação, ganha o estatuto de matéria boa para transformar. É nesse momento que se abrem os espaços no corpo, através do alongamento que prolonga os membros, que afasta os ossos por meio de um espreguiçar demorado. Os espaços se estendem. É preciso se abrir para o que virá, é preciso adentrar um estado de desimpedimento. Nesse momento, as dançarinas estabelecem uma espécie de reconexáo consigo mesmas, aumentando sua "escuta interna", sensibilizando a consciência de seu corpo. "Expandindo, abrindo espaço nas articulaçóes, aquecendo esse contato com o chão, usando o chão para massagear cada volume do corpo, ativando a sensação de contato, de pressão no chão", diz Adriana, ao passo que conduz o alongamento. 
Enquanto guia o aquecimento, Adriana muda sua entonaçáo, que em ressonância com o estado do corpo se alongando se torna mais voluptuosa, prolongada, sussurrante. Alonga-se também, portanto, o espaço entre as palavras. "Aquecendo a musculatura pertinho da coluna, levando nossa atenção para a respiração. Aproveita o apoio para espreguiçar as articulaçóes, o rosto", sugere ela. É langorosa e demorada a fala que conduz o preparo desses corpos. "Beirando cada célula. Expandindo as extremidades."

O corpo, ao passo que se prepara, vai entornando seu estatuto, se transfigurando em artigo bom para morfoses. Trata-se de um aproveitamento, cujo efeito é a intensificação da espessura humana. No preparo dos corpos, seu imaginário é tramado de forma a exaltar suas frequentaçóes com o chão, que lhe massageia cada tamanho de intensidade.

Fleshdance é uma coreografia de variaçóes de intensidades emocionais composta por experiências físicas, carnais, acionadas pelo ato de respirar. Fleshdance expóe uma corporeidade ativada pela intensificação dos afetos. Propóe um corpo movido pelos órgãos, poroso, com possibilidade de afetar e ser afetado pelo outro. Um corpo que permanece sempre em constante transformação. Fleshdance é também o cansaço do ato de consumir e de descartar, é tentar resistir existindo, potencializando cada experiência. (Fleshdance - Programa da obra)

Fleshdance é uma espécie de dança respiratória que tem o pulmão por centro nervoso. Tudo começa com uma investigação da própria respiração, que é aqui acionada como motriz de variação de ritmos e qualidades corporais. Trata-se de uma semântica respiratória em que os pulmões, reais e imaginados, se tornam o lugar de onde se origina o movimento, que se expande deles para o restante do corpo.

Esses corpos, "movidos pelos órgãos", têm de fato nos pulmôes o ponto em que sentem o movimento. Por isso os pulmóes são "ativados", todos os dias, no início dos ensaios e, posteriormente, momentos antes das apresentaçôes. Para essa ativação, entram em cena bexigas d'água, que cumprem a função de mimetizar e ativar, pelo peso sobre o corpo, os pulmóes.

Todos os ensaios começam por essa ativação ao mesmo tempo sensória e imaginária. "Escutando cada mudança de ritmo dessa respiração. Visualizando e sentindo a qualidade do tecido dos pulmóes. Posso usar o som para ativar as sensaçóes. Entrando mais e mais em contato com cada sensação, cada imagem, cada emoção. Mais alguns minutos para deixar a sensação expandir. Hoje eu sugiro que a gente tenha como foco os tempos, a escuta dos ritmos, as mudanças na respiraçáo, nos passos, como uma 
orquestra. Escutando os silêncios, os volumes, altos e baixos”, diz Adriana no início de um ensaio. E os pulmóes vão gerando sensaçóes que são a um tempo fisiológicas e criativas.

Elas se deitam no chão para fazer o exercício das bexigas, segurando com cada uma das mãos uma bexiga d'água que pesa sobre a caixa torácica, enquanto Adriana vai dizendo, num fluxo langoroso: "Recebendo com os pulmóes o peso da bexiga. Sentindo nas máos o movimento da respiração. Abrindo cada pedacinho dos pulmôes com a respiração. Ativando cada pedacinho do pulmão com a respiraçáo, quando eu quiser posso fazer também o som vibrar. Deixando o ar entrar, deixando o ar sair". Elas passam a produzir um som que é produzido pela respiração, numa espécie de pré-fala. "Entrando em contato com cada sensação, com cada imagem", estimula Adriana.

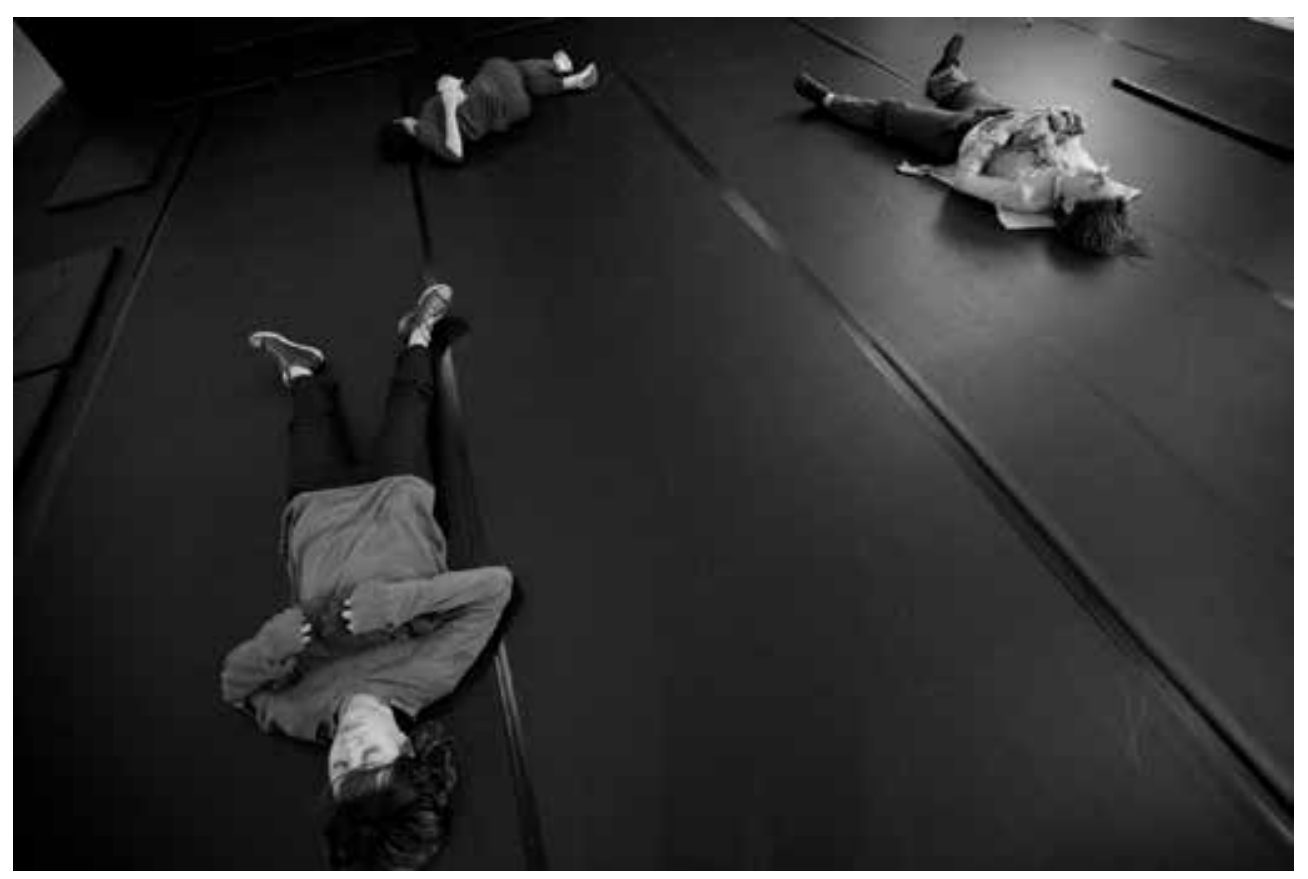

Elas bocejam, absortas, num espaço afrouxado de calmaria. "Usando a respiração para ativar as sensações, as emoções." Ao passo que Nina, Juliana e Larissa estão deitadas no chão, pesando sobre a caixa torácica as bexigas, Adriana diz: "Consciência do tempo da entrada, consciência do tempo da saída do ar, percebendo cada acontecimento dentro dos meus pulmóes, percebendo a sensação do peso dos pulmóes, do volume dos pulmóes. Percebendo a duração da minha expiração e da minha inspiração, percebendo cada sensação. Quem quiser pode usar o som para ativar a sensação, percebendo como o som passa pelo pescoço, como chega nos pulmóes, como 
vibra nos pulmóes, como passa pela boca. Percebendo cada acontecimento no meu corpo, nas minhas sensaçóes, nas minhas emoçóes, vou ativando a respiraçáo e percebendo o que vai acontecendo". Essa experiência individual de contato íntimo e imaginativo que se vai estabelecendo com a própria respiraçáo, através das sensaçóes concretas que se vão produzindo no corpo, tudo isso é fundamental na criação de Fleshdance.

E então esse compósito, essa fusão de sensações e imaginações começa a deflagrar uma dança. Ainda deitados, os corpos começam a abandonar as bexigas d'água e vão pouco a pouco produzindo movimento, movimento provocado pelo fluxo e influxo da respiraçáo, pequenos movimentos que vão se ampliando, inchando e esvaziando, os membros arqueiam em movimentos maiores, os braços se alçam, e também as pernas. Elas estáo de olhos fechados, e é como se renascessem, arfando. A respiração vai produzindo movimento, o movimento tem um caráter circular, e cresce até que impele o corpo a ficar de pé.

"Começou a aparecer uma sensação, eu fico nela, exploro, exploro, entrando mais e mais em cada emoção, em cada sensaçáo. Deixa o rosto entrar, se aparecer uma quase fala deixa entrar, explora. Apareceu um padrão, explora", pede Adriana.

Conforme elas vão produzindo movimento através da respiração, Adriana diz: "Percebendo cada entrada e cada saída do ar. Ativando a conexão dos pulmôes com as mãos. Percebendo como a respiração chega até a ponta dos meus pés, a cada duraçáo de entrada e saída do ar. Percebendo cada repouso e cada silêncio, o deslocamento do meu corpo pelo espaço, cada sensação, o espaço em volta, a proximidade das demais. Animando pela respiração a coluna. Espalhando no chão a sola dos pés. Para uma troca respiratória”.

Ao passo que dançam elas se contra-afetam. E de repente um arfar mais denso de uma dançarina produz um efeito coletivo de disparos, respiros, impulsos, deslocamentos. Os braços ganham vida própria em conexão íntima com os pulmôes. E, mais uma vez, a densidade do arfar de uma dançarina produz uma onda sonora de respiraçóes que as arrebata num movimento respiratório coletivo. A respiraçáo conduz o movimento que as conduz. 


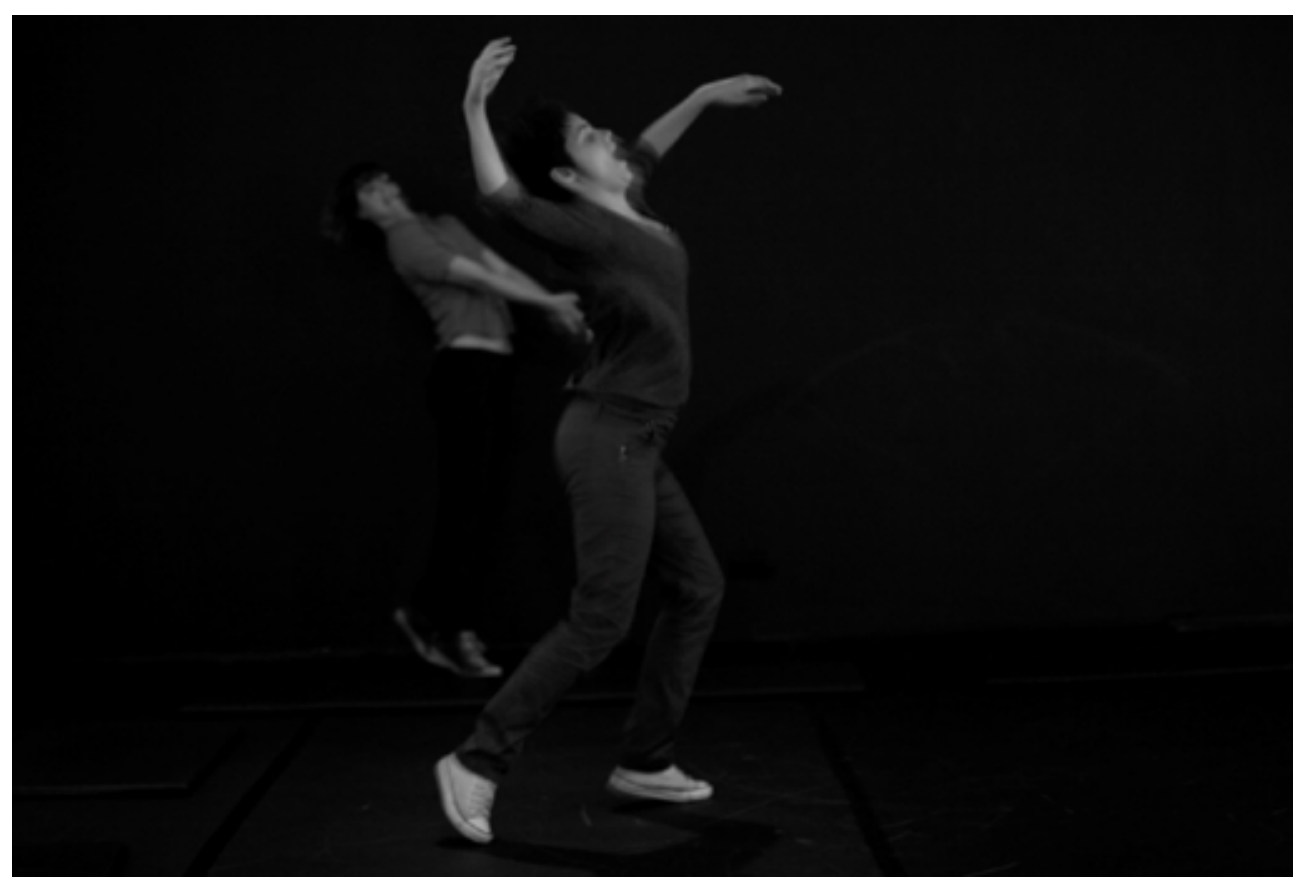

Ao passo que elas dançam essas exploraçóes respiratórias de movimento, Adriana lhes diz: "Sentindo como o volume dos meus pulmóes se expande, como se compacta, percebendo como a respiração altera o volume do meu corpo. Escuta. Deixa o rosto amassar na sensaçáo. Toma o tempo de compactar a sensação até ela explodir”.

Ao chegarem ao rosto das dançarinas, os impulsos provocados pela respiração vão produzindo nelas feiçóes, ora grotescas, ora alegres, sorridentes, agressivas, confusas. Essas "intensidades emocionais" que tomam a forma de feições são provocadas no e pelo próprio corpo. Essas feições não são planejadas intencionalmente, são provocadas por sensaçóes físicas geradas pela exploração continuada da respiração enquanto motriz de movimento, exploração que culmina em determinados estados corporais que produzem certas, ou melhor, incertas caras.

"A sensação dos pulmóes vai se expandindo para o resto do corpo. O rosto vai se envolvendo no movimento", afirma Adriana. Aqui, os corpos se encontram repletos de capacidades emocionais, porém essas capacidades não têm rumo patente, se dão numa espécie de desígnio emocional difuso. Não que se trate de comoções vãs, elas apenas não são precisas, e isso é intencional. 


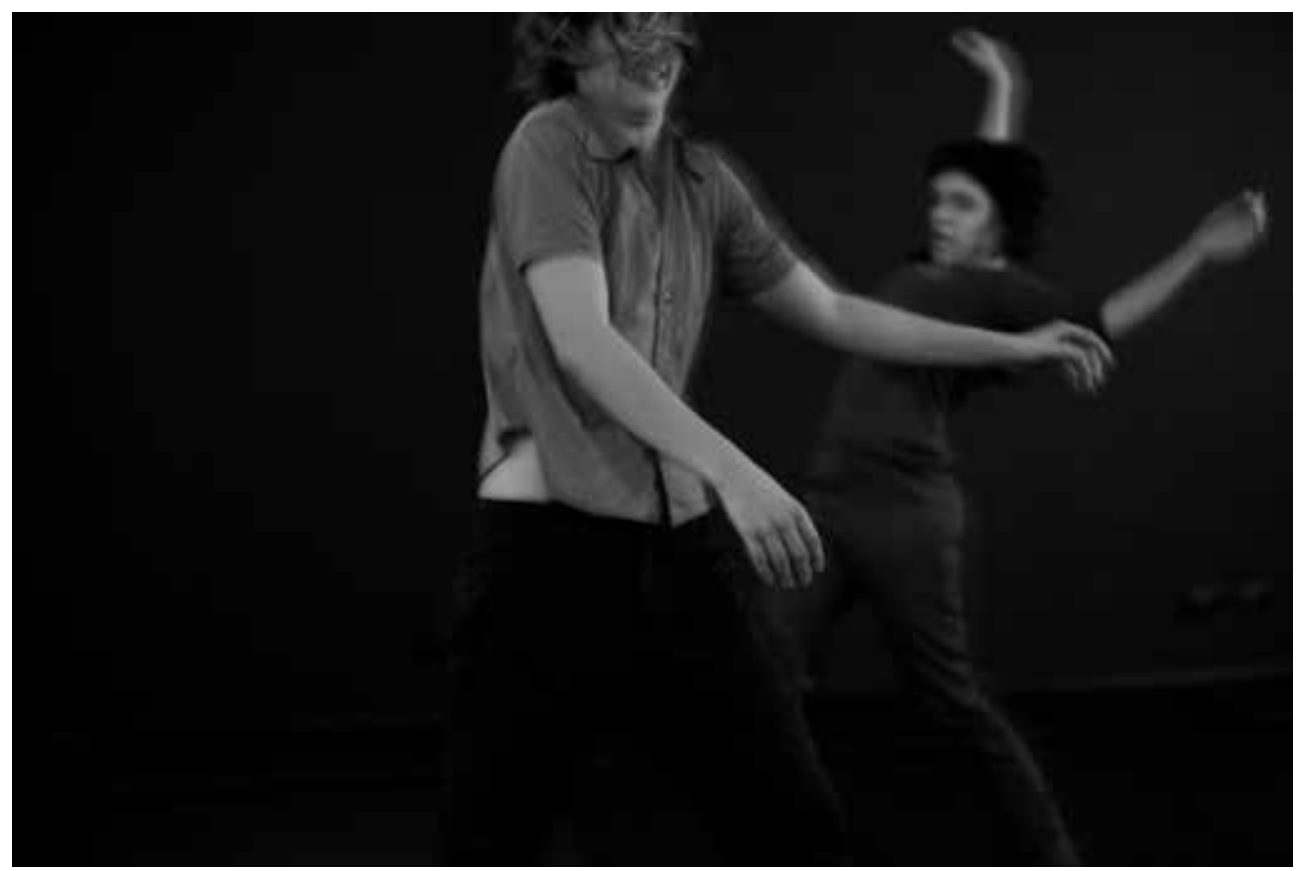

O corpo se articula para dizer, a boca se abre, os olhos te miram, assumindo a expressão do rosto, e, antes que o primeiro fonema apareça, tudo se torna de repente outra coisa. A respiração comanda os estados. $\mathrm{O}$ ar que entra, o ar que sai. Os pulmóes se tornam balóes que inflam e esvaziam, levando o corpo pelo espaço conforme a força e a direção do ar. A respiração muda o tempo que produz o movimento que desloca o corpo que respira. $\mathrm{O}$ pulmão reina. Em Fleshdance se dança a própria respiração. A dinâmica respiratória estabelecida pelas dançarinas vai criando movimento. E por estar a respiração intimamente ligada à fala - somos capazes de falar porque somos capazes de controlar a respiração -, são vários os momentos do trabalho em que se tem a impressão de que as dançarinas estão prestes a proferir algo, mas jamais o fazem. É intrigante. Uma espécie de doideira eficaz, de disfunção funcional, a dançarina te olha e te desolha, te procura e te evita, parece presa num estado eterno de indecidibilidade, numa aporia profunda entre o fazer e o não fazer, entre o falar e o não falar. $E$ isso não se resolve.

"Deixa o corpo te surpreender", Adriana diz aos corpos que se experimentam. A dança aqui é um movimento que arrebata depois de uns silêncios que são pequenas esperas pelo corpo que vem. "Por mais que se ensaie sempre haverá esse lugar do desconhecido", conta Adriana. Nina, dançarina do Núcleo Artérias, me revela: "Para mim é tudo meio nebuloso, às vezes nem a gente sabe direito o que está fazendo".

As dançarinas do Núcleo Artérias são pessoas que fazem do corpo lugar de especulação, que frequentam o próprio corpo enquanto lugar ainda e sempre desconhecido, encontrando para ele identidades cambiantes, numa espécie de dança-sonho. $\mathrm{O}$ regime identitário aqui permite construçóes e reconstruçóes a cada vez, a cada processo, a cada retomada. 
Uma referência para Fleshdance é a obra Fluxo-floema, de Hilda Hilst (1970), em que os enunciados são produzidos não por uma consciência única e solitária, são fragmentos narrativos que provém, alternadamente, de diferentes lugares, frases que brotam prolíficas a disputar trechos incertos, instáveis na montagem discursiva. O que Hilst apresenta em Fluxo- floema como registro de subjetividade é o drama da posição do narrador. Uma espécie de perspectivismo narrativo, em que o que se encontra fixo é o ponto de vista da enunciaçáo ao passo que se deslocam através dele uma sucessão de narradores, que precariamente e sem distinçóes vão se apossando do discurso. O que temos aqui é uma espécie de narrativa da possessáo, ao longo da qual diferentes perspectivas habitam, uma a uma, o presente da enunciação.

Mas abóboras, não sei. É matéria calada, ou fala como tu? Então come de mim, me comendo me sabes. Não medita. Suga. Vai até a seiva, até a sutileza. Pesas como palha, não te escuto. Abre um caminho, abre outro, tenta, eu disse seiva, sim, eu disse suga, eu disse come de mim. Ainda me escutas?

Não, da garganta não sei. Sei do vazio. Tudo tem nome e ao mesmo tempo não tem. Fazes o possível para que eu não te entenda.

Tem movimento alado? Conta-me mais. Caminha sobre o charco?

Fica mais claro, toma tempo. Limpa o vazio que preenchi. Deves poder limpar, porque tudo que eu fiz, fiz para o teu gozo, limpo para sujares, sujo para limpares.

Estou todo dentro, de perfil também. Sou de frente, sou sempre inteiro, usa a linguagem fundamental, sem essa que disseste.

Chama-se língua, essa?

Nada é junto de mim, nada é distante. Abarco o meu próprio limite.

(HILDA HILST, 1970)

A dança que constitui Fleshdance é análoga à prosa de Hilda Hilst. Em vários momentos tem-se a sensação de que essa dança contemporânea do Núcleo Artérias é um libelo contrário a certas normatividades comunicativas. Adriana nos explica: "A comunicação entre os sujeitos é sempre frontal. Aqui, quanto menos frontal a comunicação, melhor. O sujeito é aqui decomposto, e o modo como se articulam as partes do corpo, cérebro, peito, mãos, rosto, coluna, quebra a ideia de uma intenção, o corpo se torna polifônico. Isso de alguma maneira dilui a ideia de um sujeito da ação".

Articulaçóes ganham proeminência em relação às partes, as relaçóes se sobrepóem aos termos e a intensidade passa a ser mais importante que o significado.

De fato, os estudos técnicos do corpo em movimento produzidos ao 
longo dos ensaios do Artérias e durante as aulas de Adriana, que frequento desde o início de 2012, pressupóem e produzem uma grande autonomia das partes integrantes do corpo, de forma que, no limite, cada parte possa se pensar em separado, produzindo um efeito desconjuntado, digamos, no corpo que dança, tornando-o um corpo polifônico, que faz deslocar o sujeito suposto da ação. A dança contemporânea do Núcleo Artérias converte cada parte do corpo num corpo inteiro.

Por um lado, a prática de escutar algo que não é exatamente sonoro, "escuta interna", por outro a presença do som do arfar da respiração enquanto elemento poético de uma dança. Elementos que retomam e, ao mesmo tempo, impóem problemas ao formalismo lévi-straussiano. A presença da voz, desarticulada, ou mesmo da fala, articulada, em diversas obras contemporâneas de dança, demonstram o problema de tais separaçóes por demais categóricas. Sáo usos da voz, ou mesmo da fala, que expandem a apreensão das palavras, dos fonemas, dos sons vocais, uma espécie de poesia táo concreta quanto o corpo que a suporta. Algo que visa dilatar significâncias. À medida que encarnamos a estrutura lévi-straussiana, suas divisóes por demais abstratas ganham movimento, e as próprias fronteiras entre mito, linguagem, matemática e música entram também em movimento. Eis a potência da dança. Eis a razão de nossa curiosidade frente à mesma.

O que nos parece mais potente: a possibilidade de pensar o rompimento ontológico do "1 corpo $=1$ pessoa". No caso da obra Bananas, cujos excertos etnográficos vêm a seguir, são diversos os momentos em que podemos pensar " 1 corpo $=$ três pessoas", ou " 1 pessoa $=3,4,10$ corpos". Corpos que pensam corpos através de pessoas. A dança possui uma especificidade quanto ao "reconhecimento da alma no corpo", de que fala Lévi-Strauss, pois na dança corpos podem vir a se reconhecer em outros corpos e a ontologia da dança pode ser a do ser enquanto outro, enquanto outro corpo. Implosáo categórica que impossibilita a concepção do ser essencialmente circunscrito ao próprio corpo, corpo que é a esfera por excelência da integralidade do indivíduo moderno ocidental. A integralidade corporal do indivíduo ("1 indivíduo = 1 corpo", o corpo enquanto princípio do indivíduo) não resolve a dança. Ao mesmo tempo em que se valoriza, na dança contemporânea, a dança de cada pessoa, a singularidade de cada corpo, há outros aspectos que terminam por anular a possibilidade, digamos, moderna, de "1 pessoa = 1 corpo $=1$ dança".

Isso transborda a dança. Por exemplo: em Fleshdance, o público está den- 
tro do palco e a plateia está vazia. A dança se dá num estado de proximidade em relação ao público, num estado de abertura que tem o olhar como fronteira. Alguns espectadores se fecham, mas aqueles que se interessam em experimentar tal interação se dão conta de que seu olhar, suas ações faciais, pequenos gestos, são capazes de alterar o rumo do movimento, e também a expressão do rosto das dançarinas em cena. Às vezes se dá uma mistura entre os corpos e as expressóes de espectadores e dançarinas, a expressáo do rosto daqueles se torna a expressão no rosto destas e vice-versa. Onde aquilo começa, onde termina, não se sabe ao certo. Onde começa um corpo e termina o outro, tampouco. Dá-se aqui uma breve diluição do sujeito da ação. Que corpo é esse, eu pergunto a Nina, dançarina do Artérias, "Um corpo sem pessoa definitiva", ela me diz, e acrescenta, "O ocidente tem muita dificuldade com isso".

\section{Bananas, excertos etnográficos de uma dança digestória}

Em janeiro de 2013, o Núcleo Artérias dá início ao processo criativo de seu novo trabalho de dança contemporânea, Bananas. A obra é dirigida por Adriana Grechi, dançada por Carolina Minozzi, Nina Giovelli e Larissa Ballarotti - posteriormente por Lívia Seixas -, com vídeos de André Menezes, trilha sonora de Dudu Tsuda e iluminação de André Boll.

Bananas é uma espécie de desenvolvimento de Fleshdance. Seu processo é em grande medida um processo de transformação das transformaçóes geradas ao longo de Fleshdance. Esses dois processos podem ser pensados enquanto versões de uma mesma obra. "O Bananas é o bicho que saiu do Fleshdance", me conta Carol. Mas ao invés do sistema respiratório, Bananas tem por campo exploratório, concreto e imaginário, o tubo digestório, seus órgãos e sua semântica. "No tubo digestório se dá o encontro entre o desejo e a nutrição, desse encontro resultam completas transformaçóes, coisas são aí digeridas, alteradas e expelidas, essa é sua semântica”, me explica Adriana.

Aqui elas vão explorar as possiblidades de movimento que atravessam o tubo digestório, com a possiblidade de se alcançar o espaço com o ânus, com a boca, com a possibilidade de comer e cagar o espaço.

Todos os dias, assim como em Fleshdance, elas iniciam o aquecimento, o encaminhamento corporal, com as bexigas d'água. Dessa vez, as bexigas d'água servem à sensibilização do tubo digestório. Elas então passam a estudar o sistema digestório, a começar pela boca. Ao longo da construção de Bananas, várias foram as horas aproveitadas em exercícios de sensibilização da boca enquanto centro nervoso. "A boca dá início aos demais sentidos. 
O bebê pensa com a boca, o corpo todo responde aos desejos da boca, o primeiro sentido é a boca", afirma Adriana.

Num determinado momento, as dançarinas se encontram deitadas a minha frente em posição fetal, chupando os dedos, de olhos fechados. "Para ativar a cavidade bucal em conexão com o restante do tubo digestório", explica Adriana. Nesse momento, elas mesclam dois direcionamentos. A capacidade que a boca tem de dar direção ao gesto e o esticar do bebê na barriga quando está prestes a nascer. "O suporte é a boca, para alcançar, buscar e recolher as imagens”, diz Adriana.

"Explorando cada sensaçấo, cada necessidade do tubo. Toda possibilidade de flexionar, de estender, toda possibilidade de ativar as extremidades", propóe Adriana ao passo que conduz as exploraçóes. "Vamos dedicar um bom tempo a essa exploração do tubo. Tubo elástico, resiliente", sugere ela. Ao longo do processo, elas se demoram diariamente nessa exploração.

No início de um ensaio, Adriana menciona a aula de hoje pela manhá, ressaltando a conexão entre os braços e a boca. Conforme a boca alcança, os braços também.

"Entrega o corpo, deixa o peso do corpo ceder à gravidade. $\mathrm{O}$ chão empurra o peso de volta. Isso produz tônus. $\mathrm{O}$ corpo cede. $\mathrm{O}$ chão faz uma pressão e isso dá forma e tônus. É fisiológico. Com isso se vão integrando as partes do corpo. E aí cada uma vai fazendo seu caminho pelo tubo", diz Adriana, conduzindo o início da exploração.

Deitadas de barriga para cima, muito vagarosamente, elas rolam a bexiga d'água ao longo do peito, da barriga, do pescoço, da boca, do ânus, dando peso à imaginação ativa do tubo digestório ao passo que de fato sentem o peso da bexiga sobre o corpo, dotando a imaginaçáo de um sentido sensório. Os reflexos bucais são um princípio de exploração dessa dança, em que a boca e os braços entram em profunda consonância, alcançando o espaço juntos, reagindo em uníssono. "A boca alcança na direção do toque", afirma Adriana.

A bexiga pesa e ativa o sentido do tubo. A sonorização por meio da voz dá volume ao corpo e coloca em movimento essa imaginação de uma coisa real dentro de si. O tubo ganha necessidades e passa a comandar o centro do desejo. "Ativando os desejos do meu tubo."

Ainda deitadas, de olhos fechados, elas vão deixando as bexigas de lado, também deixando que a sensação produzida nesse primeiro momento ganhe proporções de dança. "Vou vivenciando cada sensação, cada imagem. Essa qualidade superelástica, resiliente, que o tubo proporciona. Toda possibilidade de a boca alcançar, de a boca comer o espaço. Toda possibilidade de o ânus alcançar, de cagar o espaço. A boca alcança e recolhe. $O$ ânus também. As pernas conectadas com o ânus, os braços com a boca. Toda essa possibilidade de alcançar e recolher". 
"Os membros viram tubos", sugere Adriana. Aqui o corpo se organiza para se desorganizar mais tarde, suas partes invertem e transformam suas funções. As dançarinas vão estabelecendo conexôes entre o tubo digestório e os membros. Conexóes que produzem outros tipos de causalidade. Os membros se tornam órgãos, os órgãos se tornam membros. As partes seguem sendo partes, mas cada parte ganha sua espécie de independência recriativa. Sem dúvida, e sobretudo, é preciso resguardo para deixar-se vir desse jeito.

Depois de alguns vídeos de bonobos e chimpanzés, que se tornam aqui inspiraçôes poéticas, depois de uma imagem impressionante de um gorila dançando break, elas se aquecem, se alongam. "Explorando minha vida no meu tubo de macaco", pede Adriana. Depois do exercício com as bexigas d'água, Adriana sugere que elas dancem e façam macacos por meio da sensação do tubo. Elas agora exploram esses macacos. "Criando uma imagem do meu tubo, vou entrando mais e mais nesse estado macaco. Apareceu um estado, explora." Conhecer aqui é tornar-se (macaco). Uma imensa, intensa e contínua concentração perceptiva para abstrair-se das utilidades da expressão corporal. $\mathrm{O}$ sentido aqui não pode ser rigorosamente explicitado ou codificado. A dança não separa corpo e obra. Isso a torna singular.

Pouco a pouco elas vão adentrando o estado corporal específico de que se faz esse trabalho, esse transe-tubo digestório. Aos poucos elas vão se livrando das bexigas e os corpos vão ganhando os planos médio e alto, passando a explorar em movimento a sensaçáo da sinuosidade desse tubo. "Pouco a pouco, quando eu quiser, vou entrando no meu tubo de macaco. Macaco que come, macaco de intestinos pesados. Intestinos volumosos, em conexão com os pés. Ótimo, já começou a aparecer o bando!”, exclama Adriana. Elas então vão para o plano alto, bípedes. Grunhidos advêm de suas bocas, acompanhados por estranhas expressóes faciais. "Ótimo, intensificando o desejo. Posso conectar os pés com os intestinos. Ótimo, posso comer o espaço!”

De fato, elas se tornam um bando de macacos, que vem em minha direção, parece que vão me atacar. "Esses macacos às vezes viram um bando de tubos e depois voltam a ser macacos", explica Adriana. Elas chegam bem perto de mim, quase encostam. E pensar que eu almocei com esses macacos hoje. Onde foram parar Nina, Carol e Larissa?

Elas aderem a esse estado macaco, até Adriana parece espantada. Ela se mostra bastante satisfeita com a lógica intermitente desse bando, que se faz e logo se desfaz. "É uma supercomposição", diz ela. É impressionante como seus corpos se comunicam, como se contagiam nesse estado de bando. Bananas parece ter seu funcionamento próprio, o que estava dentro da cabeça de Adriana passa a estar fora dela, nos corpos de Nina, Carol e Larissa. Dentro e fora. 
"Vou incorporando o macaco", propóe Adriana. Elas seguem macacos, explorando sem medo as imagens as quais vão se tornando. Elas habitam o estado macaco e se tornam um bando. Elas náo querem saber que sabiam o que está por vir, o que exatamente vai acontecer, que direção irão tomar seus corpos. É paradoxal, mas elas ensaiam sustos que se darão a si mesmas.

As três dançarinas entram em cena e se sentam entre os espectadores que estão no palco. Num semicírculo, todos se entreolham. Elas têm um olhar de dar medo. Parte dos espectadores está no palco, outra parte na plateia. Metade dos espectadores é cena, outra metade não é. Em Bananas metade da plateia fica cênica.

Três mulheres entram em cena, de peruca, vestindo camisetas de numeraçáo masculina, e se sentam nas três cadeiras reservadas para elas em um semicírculo de cadeiras onde se encontra parte dos espectadores, os demais espectadores estáo sentados na plateia. As dançarinas se sentam, assumindo poses notadamente masculinas, o olhar pesado, provocador, e em alguns segundos, conforme elas mudam de posição, conforme cruzam e descruzam as pernas, sempre nesse tom, torna-se evidente que elas não usam calcinha. Mulheres de peruca, camiseta, perna aberta, sexo à mostra e muita pose de macho. Elas olham direto no seu olho e elas se parecem homens.

Para nós, espectadores, a imagem de uma nudez vaginal num corpo feminino virilizado: corpo e sexo se confundindo. Sexo em movimento, o corpo dançando uma imagem distorcida de mulher nua, uma temática política engajada num pensamento de corpo que póe esses corpos de mulheres numa espécie de movimentação masculino-intestinal.

Há um momento inicial da obra, portanto, em que elas se sentam em meio ao público, uma a uma, em posiçôes viris. O público se encontra repartido entre o palco e plateia. Elas se parecem homens. O jogo proposto aqui por Adriana é ir se apropriando das feiçóes machas uma da outra. "Escolhe as características que achou mais masculinas", pede Adriana. Elas adentram um jogo de réplicas, por meio de atos miméticos. Isso se torna fundamental à construção de Bananas, o modo como elas vão produzindo estados corporais digestórios, estados que váo gerando certos tipos de movimento, dos quais elas vão se apropriando umas nas outras. Elas vão replicando umas as poses e masculinidades das outras e isso dura um bom tempo ao longo dos ensaios, e é repetido diariamente. "A gente pode estudar os irmãos, namorados, amigos", sugere Adriana, se referindo ao mundo, digamos, real.

Nesse momento em que se encontram sentadas em meio aos espectadores, elas se assemelham a imagens, habitam poses rijas, que vão se alternando lentamente e depois rapidamente. Essas poses sáo apropriaçóes de 
poses masculinas que elas vão encontrando no cotidiano, e são também apropriações das poses umas das outras, e são também apropriações de posturas masculinas que elas encontram aqui e agora, no público. Nesse momento, sentadas, alternando poses, elas habitam a mesma qualidade corporal que se dá ao longo de todo o trabalho. Quando em cena, elas vão se apropriando das poses dos homens que estáo sentados no palco, prontamente transformando essas poses por meio dos estados corporais em que elas se encontram.

Elas ensaiam minuciosamente esse sentar, o olhar, a pose, o peso que acompanha esse ato. Conforme elas se sentam, conforme vão alternando poses, elas vão descobrindo, reconhecendo os apoios mais masculinos do cotidiano, reconhecendo-se homens pelo apoio das mãos, dos braços, das pernas, da cabeça, pelo peso dos membros. Ao longo dos ensaios, elas percebem que o acabamento mais definido das extremidades, mãos e pés, é mais feminino. "As extremidades masculinas são mais pesadas, largadas, inacabadas", elas constatam.

Ficar nu em público é transformador. É forte. Libera forças, desata amarras. Ficar nu em público é todo um conhecimento que se adquire, uma passagem transformadora, uma sabedoria nova. Por baixo de toda roupa reina outra roupa, a nudez. Tirar e colocar a roupa se torna dançar. Tirar e colocar a roupa já não cumpre um objetivo óbvio, uma moral óbvia, tirar e colocar a roupa se tornam gestos públicos, a nudez se torna um gesto de intimidade pública.

Elas se despem da cintura para baixo e começa o jogo. Quando elas se sentam, um tom agressivo lhes toma o rosto, elas se olham, e olham para o público, se olham e olham para o público. "A gente pega a masculinidade da outra e intensifica", propóe Adriana. Elas se apropriam umas das outras, é visível, elas se afetam e se citam. Se apropriam dos gestos uma das outras.

Esse jogo de apropriaçóes tem suas particularidades, pois não se trata de imitação no sentido de uma reprodução fiel, mas de coabitar estados corporais umas das outras, estados que não necessariamente geram o mesmo tipo de movimento, mas sim um mesmo tipo de qualidade. Enquanto elas exploram o movimento a partir do tubo digestório, Adriana as orienta a se apropriarem, num dado momento, "do tubo da Nina, dos sons do tubo dela". Elas estudam o estado produzido pela movimentação de Nina, estudando os movimentos que seu corpo inventa ao imaginar-se um grande tubo digestório. Então algo que não é exatamente visível, daí a particularidade dessa mimese, passa a ser compartilhado pelas três dançarinas. Dentro e fora do tubo se tornam repartiçóes que se aderem, num dado momento elas dançam dentro do tubo digestório de Nina, por meio dele, depois, do de Larissa, depois, do de Carol. "Vou me apropriando dessa 
variação, do som, da flexão extrema do tubo da Nina”, propóe Adriana. Há um jogo de apropriaçóes que é aqui fundamental, apropriaçóes que se fazem diretamente no corpo, como se três pessoas dançassem um mesmo corpo. Enquanto Nina explica às demais o seu movimento "rave", Adriana diz: "Cada uma do seu jeito, mas todas no mesmo. Se uma coisa te interessa aqui, você fica. Tem que sentir".

E então é a vez do "repertório Carol", como elas dizem. Carol tem vários micropersonagens de duração exígua. Elas então passam a estudar o "macaco go-go-boy", nome que dão a um padrão de movimento produzido pelo estado corporal adentrado por Carol. Nina e Larissa aprendem com ela a fazer esse macaco que ela faz, "o macaco que ameaça em círculos", define Adriana. Nina e Larissa passam um bom tempo dançando e explorando suas imagens de "macaco go-go-boy", se apropriando de cada tipo de impulso, das ondas que vêm do tubo digestório da Carol, surfando essas ondas. Unidades discretas de movimento, carregadas de uma qualidade intestinal, vão sendo coletadas, mimetizadas, coabitadas por elas a partir da exploração individual de cada dançarina. Longas horas de exploração, para chegar a essa indistinção, numa dança que imiscui corpos uns nos outros.

Depois é Larissa quem passa a ser objeto da mimese de Nina e Carol. "Larissa, como é a história dos dentes do macaco, o repuxar dos lábios do macaco?", pergunta Adriana. Larissa demonstra, e Nina e Carol se apropriam desse gesto. Apropriaçáo que transforma, recurso fundante dessa dança. "Cada uma delas tem suas próprias imagens, partindo dos mesmos princípios físicos", explica Adriana.

Nina vai explicando às demais cada uma das suas qualidades, o encadeamento que se dá entre elas. Depois, Carol e Larissa fazem o mesmo, elas explicam suas invenções de corpo para que as demais possam melhor compreendê-las e dançá-las. É como se mapeassem os cômodos de suas casas para que as demais ali se sentissem mais livres. Elas vão explicando o funcionamento de cada um dos seus movimentos, onde começam, como e para onde váo. Elas sabem dizer o modo de cada movimento do roteiro, como vão se encaixando um no outro, se transformando um no outro.

Cada uma delas vai estabelecendo repertórios pessoais de qualidades masculinas e ao mesmo tempo digestórias. Posteriormente, se dão longos jogos de apropriaçóes desses repertórios. Elas entáo aprofundam os estados corporais, explorando as apropriaçóes que vão fazendo umas das outras. Com o passar do tempo, a partir da exploração do tubo digestório enquanto motriz, cada uma das dançarinas vai encontrando diferentes padróes de movimento, que passam a ser designados conceitualmente, ainda que às vezes transitoriamente, por meio de rótulos que são imagens suscitadas pela qualidade de movimento de cada uma. Nina, "bêbado, boxeador". Larissa, "largado". Carol, "macaco". Esses sáo alguns exemplos dessas de- 
marcações. Esses padrões estão intimamente ligados ao estado corporal que os gerou, e é por meio desse estado que elas vão se comendo, absorvendo umas as qualidades das outras. "Começou a aparecer uma variação de ombro, de impulso, de ritmo, eu exploro - apareceu uma qualidade, a gente radicaliza, explorando até o limite a necessidade e o desejo inerentes a essa qualidade", explica Adriana. Imitar o devir do outro até ser o desejo do outro, o que o outro será. Imitar o percurso do outro até ser. Um processo cujo fazer é a invenção de um modo de fazer-se.

Num determinado momento do processo, Larissa me conta que a cada dia que passa sente dores (musculares) numa regiáo diferente do corpo. Ela explica que isso acontece porque ao mimetizar o movimento de Nina e Carol, ao requerer de seu corpo que dance o corpo delas, ao replicá-las no seu corpo, ela se descobre noutros corpos, se faz outros corpos, e isso dói um tanto para acontecer porque os impulsos passam a ser acionados de outro jeito. Um corpo que é também os corpos que estáo fora dele, um corpo que transfunde em seu o sangue alheio, em seu o espaço que o cerca. Um corpo que se comove ao comunicar sua permeabilidade.

Mais tarde, Larissa me conta sobre a importante questão, nessa dança do Núcleo Artérias, de se repetir, repetir sempre, até constituir segundas naturezas, que passam a constituir o corpo, segundas naturezas que se dão pelo exercício continuado, repetido e repetido, de dançar o corpo que a cada agora se é até fazer um corpo outro. A repetição aqui é o que faz instaurar pequenos desvios, a ideia é repetir, o efeito é diferir, através de uma dança que cria, que fraciona e testa. Repetiçóes que geram invençóes que são descobertas. Primeiro elas exploram um movimento, suas possibilidades, suas extensões, depois enxugam esse movimento, e a síntese se faz, ganhando força. Elas vão fracionando a dança e, conforme o fazem, elas repartem o movimento em pedaços menores, discretos. Com isso, abrem espaços, distendendo o corpo, estendendo também o tempo, a experiência do tempo no corpo. Esses fracionamentos vão dilatando o tempo e aumentando o campo de açáo. Isso permite que venham à tona potenciais outros de relação com o mundo, com o outro e consigo.

\section{Danças integram séries de transformações}

Em Estilo e significado na dança umeda, Alfred Gell (1999) lança as bases de uma análise estrutural da dança, analisando em particular uma sequência de danças rituais, dançadas entre os Umeda da Papua Nova Guiné ao longo do Ida. Nesse contexto, Gell aponta para a possibilidade de se pensar a dança enquanto sistema de transformaçáo de padróes motores previamente existentes, corpos enquanto transformaçóes de outros corpos. 
$\mathrm{Na}$ dança umeda, os dançarinos incorporam personagens míticos e a ideia central de Gell é a de que cada um dos sucessivos personagens dançados na arena ritual, ao longo dos dois dias do Ida, é uma transformaçáo dos personagens que lhe precedem e, ao mesmo tempo, uma aproximação progressiva em direção à apoteose da cultura, que se dá sob a égide do herói cultural, o arqueiro vermelho, o ipele, o último a entrar em cena.

Os dançarinos iniciais são os "casuares" - homens pintados de preto, vestindo máscaras que se assemelham a arbustos. Segundo Gell, eles representam a natureza, o selvagem, o incontrolado, o primordial. Conforme avança o ritual, os dançarinos desempenham papéis que se afastam, progressivamente, desse estereótipo inicial. O argumento de Gell é que os papéis desempenhados pelos dançarinos vão progressivamente se afastando do polo natureza em direção ao polo cultura. Por exemplo, no segundo dia do ritual, aparecem os dançarinos "peixes", emblemas da masculinidade, eroticamente atraentes, evocando temas culturais, em especial por meio de suas máscaras, que são construídas do "cultural" coqueiro em oposição ao "natural" sagu, que constitui a máscara dos casuares.

As máscaras utilizadas no Ida formam uma série, e cada máscara pode ser transformada nas outras por meio de operaçóes simples. Por exemplo, a máscara ipele é uma máscara peixe miniaturizada. É, pois, através da padronização desses contrastes e continuidades entre as máscaras, enquanto uma série, que elas adquirem significado. A série de máscaras, enquanto grupo de transformação de uma armação básica, recapitula as oposições sociológicas entre várias classes de homens em diferentes estágios do ciclo da vida em referência à variedade de estilos de cabelo que essas classes de homens adotam. Essa é a estratégia do ritual como um todo, desde que o propósito que lhe subjaz é precisamente a encenação, por meio de um drama ritual, dos processos gerais de regeneraçáo biossocial, uma tarefa que culmina com a apariçáo dos arqueiros ipele, que são homens novos, produzidos durante o curso do próprio ritual. As máscaras codificam esse ciclo regenerativo, e para compreender seu significado é necessário considerá-las enquanto uma série de transformação, mais do que uma simples série de máscaras individuais. Nesse ritual, o Ida, os papeis dançados que se sucedem são estabilizados por meio de características que se sucedem numa ordem.

Nessa dança umeda não só as máscaras, como também uma série de outros elementos, fortalecem o argumento da transformação progressiva, como as cabaças penianas utilizadas pelos dançarinos, que ao longo do ritual se tornam menores e mais discretas, o mesmo ocorrendo, por fim, com a dança em si, cujos movimentos vão se tornando cada vez mais contidos e cada vez menos amplos. E é a dança como série de transformaçáo, em analogia às máscaras e a outros objetos, o que Gell busca compreender. 
Segundo a interpretação inicial de Gell, no continuum umeda entre selvagem e civilizado há um contraste entre o dançar selvagem, desenfreado, dos casuares em oposição ao dançar contido dos arqueiros ipele, cujo estilo relativamente reprimido, diz Gell, expressa o constrangimento da espontaneidade que a cultura impóe.

Para Gell, uma das dificuldades que impedem progressos no campo da antropologia da dança tem sido a necessidade de uma notação dos movimentos que combine precisáo com algum grau de legibilidade para os leigos em dança. Máscaras podem ser simplesmente reproduzidas, mas essa redução gráfica não é factível no que concerne a uma dança. É então, por meio de material filmado, que Gell constrói, frame por frame, um modelo da dança umeda enquanto uma série de variaçóes sobre uma armadura básica.

Segundo Gell, eis seu argumento principal, cada uma dessas danças-personagens do ritual umeda pode ser traduzida enquanto uma diferente maneira de se andar [gait]. Através desse sistema de notação, Gell desenvolve seu argumento de que o padrão normal da marcha Umeda, o modo mesmo como caminham os Umeda, é a armação básica da dança Umeda. Os diferentes estilos de movimento adotados pelos participantes do Ida são séries de transformaçóes de uma única forma, o padrão normal da marcha Umeda, que pela dança é expandido, contraído, esticado, sem, contudo, perder sua unidade essencial.

O princípio adotado por Gell, de que a dança umeda se dá em relação a um padrão motor pré-existente, que é a caminhada, é um princípio potente. A dança mantém, de fato, uma relação intrínseca com o caminhar, algo solidamente mantido pela referência habitual ao "passo de dança". Tal princípio pode ser expandido, compreendendo-se toda dança enquanto transformação intrínseca do que não é dança.

Alfred Gell afirma que não há, entre os Umeda ou talvez em lugar algum, uma fronteira clara entre dança e não dança. No entanto, é verdade que há um intervalo, um limiar impalpável, que é atravessado quando o corpo começa a dançar, em vez de simplesmente se mover. Esse intervalo, afirma Gell, é menos uma questão de movimento per se do que de significado, pois o que distingue os movimentos da dança dos outros movimentos é o fato de que aqueles possuem significados de dança afixados neles. Mas existe, prossegue o autor, um paradoxo fundamental à questáo da dança, pois que origem podem ter esses significados de dança senáo os contrastes padronizados frente aos movimentos cotidianos de não dança? A dança parece se separar da não dança por sua atipicidade, seu caráter anormal, não mundano, mas a dança adquire seu significado ao remeter-nos sempre de volta ao mundo das açóes mundanas, para o que esses dançarinos estariam 
fazendo estivessem eles fazendo outra coisa que não dançar. A dança, portanto, escapa da não dança para retornar a esta ao passo que a transforma.

Segundo Gell, os significados da dança se originam através de um processo no qual elementos, ou componentes dos padrões motores de não dança são apreendidos, estereotipados, em geral com algum grau de deformação e exagero, e estabelecidos num determinado contexto. A lógica da dança é, nesse sentido, muito semelhante à lógica da brincadeira. A mensagem "isto é dança", como a mensagem "isto é brincadeira" (BATESON, 1972, p. 151) é uma metamensagem, que estabelece a transação comunicativa subsequente em seu contexto lógico correto. Segundo Gell, a funçáo do estilo na dança, do maneirismo imediatamente reconhecível, mas comumente impalpável, que colore a gama das formas de dança num determinado contexto cultural, é marcar essa fronteira lógica entre a dança e a não dança.

Gell vai entáo em busca do estereótipo motor que comunica essa mudança de contexto, que estabelece a categoria da dança, com suas regras básicas, diferentes daquelas que governam a interpretação do comportamento em contextos de não dança. Gell visa demonstrar como a forma das danças do Ida são caricaturas de uma característica básica do estilo motor umeda, o seu modo específico de andar. Ele então oferece uma série de argumentos a favor dessa hipótese.

$\mathrm{O}$ argumento geral de Gell é que a dança umeda possui dois lados: estilo, que é o aspecto da dança que a separa do mundo da não dança, e significado, o aspecto da dança que remete de volta ao mundo da náo dança. Gell afirma que o que dota uma dança de estilo - separando-a da não dança - não é sua forma individual, enquanto movimento, mas a relação que estabelece a) com programas motores de não dança, e b) com outros movimentos de dança no mesmo sistema.

Danças integram séries de transformaçóes. E se o estilo na dança é essencialmente produto da deformação ou modulação de padróes motores incorporados, então ele só pode ser descrito por meio de uma confrontação com o esquema subjacente de não dança. Segundo Gell, a dança é então finalmente interpretável enquanto uma deformação estilizada da mobilidade não dançada, exatamente como a poesia é uma deformação ou modulação da linguagem, um desvio da norma da expressão que realça a expressividade.

Segundo Gell, para entender a dança enquanto um display comunicativo é preciso ir da manifestação superficial do comportamento motor ao esquema motor subjacente. $\mathrm{O}$ que significa dizer que, para compreender uma dança, é preciso desfazer o processo de estilização que faz de uma dança uma dança, revertendo as transformaçóes que esta realiza. O que valorizamos numa dança, afirma Gell, não é o comportamento motor superficial, tampouco o esquema subjacente que the dá significado, mas o intervalo que separa ambos. 
O que dizer então da dança do Núcleo Artérias?

Alfred Gell afirma que, no ritual umeda, uma série de transformaçóes se dá nos elementos figurativos, nas máscaras, no vestuário, nos próprios papeis representados pelos dançarinos e, também, na dança. Essas transformações, segundo Gell, vão progressivamente se afastando do polo natureza - o selvagem, o incontrolado, o primordial - em direção ao polo cultura, cuja apoteose se dá com o aparecimento do herói cultural, o arqueiro vermelho, o ipele, o último a entrar em cena.

Gell afirma que as danças que se sucedem ao longo do $I d a$, que também perfazem o sentido natureza-cultura, se dão enquanto transformações de um padrão motor de não dança, que é a caminhada. É a armação básica da caminhada que se oferece enquanto suporte de cada uma das danças, que operam nela modulaçóes. As danças vão, segundo Gell, do selvagem ao civilizado, do desenfreado movimento dos casuares à dança contida dos arqueiros ipele.

Num outro contexto, sob a influência de outros padróes socioculturais, minha suposição é de que as dançarinas do Núcleo Artérias perfazem, a cada processo criativo, o mesmo percurso, com a diferença de que tanto "natureza” quanto "cultura" são a princípio termos móveis, não necessariamente preestabelecidos, polaridades que se organizam conforme os desejos e a imaginação da obra na qual se encontram inseridas, mas sempre por fim apontando para uma proposição do polo "cultura", para uma proposiçáo reconstruída de ser, de pessoa, de relação, de sociedade etc. Nos termos de Gell, poderíamos dizer que o padráo motor prévio que informa Fleshdance é a própria respiração, e em Bananas, o movimento peristáltico.

Ao fazer-se a cada vez a pergunta, "Qual corpo?", a dança contemporânea refaz, a cada processo, seu corpo de origem. Na dança contemporânea, o "primitivo" é fonte de perpétua especulação. "O primitivo no sentido do que vem primeiro, do que nos antecede e constitui”, diz Adriana Grechi. A dança contemporânea faz um manejo intrincado desse clássico binômio antropológico natureza-cultura. Na dança contemporânea, de certo modo, constrói-se a cada vez uma nova natureza, aponta-se a cada vez para uma nova cultura. A cada processo uma recriação do mundo enquanto movimento, uma desestabilização sua necessária a uma reconstrução sua.

Cada obra de dança contemporânea pode ser vista como uma problematização singular dessas noçóes culturais de ser, de pessoa, de relação, da própria noção de cultura. O trabalho da dança contemporânea é repadro- 
nizar contrastes e continuidades. Contrastes e continuidades entre pessoas e corpos, corpos e corpos, corpos e espaço. A cada vez, ela busca por meio de seus processos uma espécie de regeneraçáo biossocial, fisiologicamente cultural, uma aparição refeita de seus "arqueiros ipele, que são homens novos, produzidos durante o curso do próprio ritual", e a cada vez uma recodificação desse ciclo regenerativo, uma ressignificação da "cultura" por meio de uma nova série de transformaçôes que termina por gerar corpos outros, produzidos no curso do processo criativo.

$\mathrm{Na}$ dança contemporânea há também uma espécie de continuum selvagem-civilizado, com a diferença de que as características que distinguem cada termo da oposição não estão dadas de saída, mas precisam necessariamente ser reinstauradas. A funçáo do processo criativo é justamente repor as polaridades construindo ponto a ponto seus termos.

No caso do Núcleo Artérias, o "polo natureza" estaria ancorado numa concepçáo do corpo como este se encontra estabelecido pela anatomia ocidental, dividido em sistemas, órgãos, membros. Tratado, contudo, de modo anatomicamente inventivo, pensado e experimentado através da materialidade fisiológica de seu funcionamento e ao mesmo tempo colocado em movimento por meio de uma imaginaçáo de sua própria sensibilidade, esse corpo gera uma dança que gera corpos que, a partir do polo "natureza", passam então a apontar para o "polo cultura": corpos refeitos, mulheres renovadas.

Adriana possui um repertório anatômico extenso, assim como as dançarinas do Núcleo Artérias. Elas conhecem bem, pelos nomes, os ossos, os órgãos, os ligamentos do corpo. Mas o que é notável é que a anatomia não lhes interessa senáo em movimento. Não lhes interessam as partes em si, mas as relaçóes que se pode estabelecer entre elas. Uma anatomia relacional, uma anatomia experiencial.

Em vários momentos eu as vi se sentarem frente ao livro de anatomia para estudar os componentes anatômicos do corpo e logo em seguida botá-los para mexer, numa espécie de anatomia criativa. No canto da sala de ensaios, um esqueleto descansa. Vez ou outra, Adriana se volta para ele para apontar o lugar preciso de um osso no corpo. As dançarinas se aproximam, algumas levam a máo ao osso em questão, no esqueleto depois no próprio corpo. E alguns segundos depois, assim que o osso ganha lugar no corpo, o esqueleto é deixado de lado, e os ossos que ainda vivem retomam seu movimento em plena interação com a imaginação de si que geram nas 
dançarinas. Partes do corpo ao mesmo tempo reais e imaginadas, imaginadas de uma tal maneira que o corpo passa a ter a forma de sua imaginaçáo. Unanimidade orgânica, convocação total do ser, alma que se reconhece no corpo, como diríamos com Lévi-Strauss.

Aqui, o objeto precário e provisório submetido à experimentação é o próprio corpo. O corpo aqui se torna o caminho, matéria-prima de investigação de possibilidades e modos de vida. A própria compleição corporal e suas possibilidades comunicativas ganham novas configuraçóes, experimentais.

Nessas danças que se dão primeiramente nos pulmóes - Fleshdance - e, posteriormente, no tubo digestório - Bananas -, o corpo se engaja numa desierarquização, numa busca pelas capacidades expressivas de partes do corpo até entáo confinadas à afasia, em detrimento das extremidades, mãos, braços, rosto, aparatos expressivos comumente privilegiados, que constituem nossos instrumentos comuns de captação, de poder sobre os objetos e os corpos, de controle sobre o discurso. Pulmóes, intestinos, estômago, vísceras, "o animal em nós retido há muito nos limbos do sentido" (LOUPPE, 2012, p. 63, 73), esses órgãos supostamente assêmicos passam a ter sua expressividade prestigiada, são aqui dotados de sentidos que desviam a expressividade das zonas até então privilegiadas. E as vísceras, aparentemente inarticuladas, se tornam aqui órgãos poéticos por excelência.

\section{Referências bibliográficas}

BATESON, Gregory. Steps to an ecology of mind: A theory of Play and Fantasy. Jason Aronson Inc. Northvale, Nova Jersey, Londres, 1987.

GELL, Alfred. Style and Meaning in Umeda Dance. In: HIRSCH, E. (Ed.). The Art of Athropology: essays and diagrams. Londres: The Athlone Press, 1999. p. 136-158.

HILST, Hilda. Fluxo-floema. São Paulo: Perspectiva, 1970.

LÉVI-STRAUSS, Claude. Finale. In: O homem nu. São Paulo: Cosac Naify, 2011. p. 603-670.

LOUPPE, Laurence. Poética da dança contemporânea. Lisboa: Orfeu Negro, 2012.

\section{Fotografias}

As fotografias aqui presentes são de Eric Brochu, a quem agradeço enormemente por ter feito e cedido essas fotos que tão bem fazem a este ensaio. Elas foram tiradas num dia de ensaio da obra Fleshdance. 


\section{Agradecimentos}

Adriana Grechi, Carolina Minozzi, Juliana Ferreira, Larissa Ballarotti, Lívia Seixas e Nina Giovelli.

\section{autor Renato Jacques de Brito Veiga}

É antropólogo, escritor, tradutor e aprendiz de dançarino. É graduado em Ciências Sociais pela UFMG (2009), mestre em Antropologia Social pela USP (2014) e recém-ingressado no doutorado em Antropologia Social, também pela USP. Desde 2009, Renato Jacques vem atuando como pesquisador, escritor e colaborador em projetos de criação em teatro, artes plásticas, dança contemporânea e literatura.

Recebido em 30/04/2015 Aceito para publicação em 25/01/2016 